\title{
Comparative Foliar Structure of Vicia L. Species from China
}

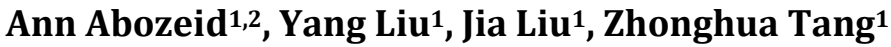 \\ ${ }^{1}$ Key Laboratory of Plant Ecology, Northeast Forestry University, Harbin, China \\ ${ }^{2}$ Botany Department, Faculty of Science, Menoufia University, Shebin El-koom, Egypt \\ Email: annabozeid@yahoo.com
}

How to cite this paper: Abozeid, A., Liu, Y., Liu, J. and Tang, Z.H. (2017) Comparative Foliar Structure of Vicia L. Species from China. Journal of Biosciences and Medicines, 5, 170-175.

https://doi.org/10.4236/jbm.2017.53018

Received: March 6, 2017

Accepted: March 31, 2017

Published: April 3, 2017

\begin{abstract}
The genus Vicia L. includes about 190 species around the world and approximately 40 species in China. The genus includes minor food crops and forage plants. This study gives a detailed description of foliar structure of some Vicia species from China. Leaf characters showed considerable variation among studied taxa including petiole and tendril length; leaflets number, length, width, shape, apex, base; blade surface, trichome shape, type, base and length; stipules shape, base, length, width and surface. Numerical analysis of these characters was used to construct a phenogram illustrating the relationship between the studied taxa and to build an artificial key to identify Vicia species. Moreover, variation in leaf characters helped in overcoming the overlapping among harmful taxa.
\end{abstract}

\section{Keywords}

Vicia, Fabaceae, Stipules, Trichomes, Numerical Taxonomy, Micro-Morphology

\section{Introduction}

Taxonomic significance of the foliar structure has been well documented [1] [2] [3]. Leaf micro-morphological characters show systematic significance in different levels in family Fabaceae [4] [5] [6]. Trichomes micro-morphology is one of the most significant leaf micro-morphological characters studied in species of different genera [7] [8].

The genus Vicia L. of the Fabaceae family includes about 190 species [9]. About 40 species have economic importance. The genus includes some minor food crops and more than a dozen forage plants; the most important is common vetch, $V$. sativa, cultivated in many countries [10]. 
Taxonomic delimitation is necessary to solve the overlapping between economic crops and harmful species. Morphological characters of leaf feature which may provides information for understanding species relationship in the genus Vicia, have not been studied. This work was initiated with the objectives of using leaf features to identify taxa.

\section{Material and Methods}

\subsection{Seed Source and Morphological Examination}

Vicia species seeds in this study were obtained from Desert Legume Program (DELEP) and The Germplasm Bank of Wild Species, Southwest China.

Seeds of each taxon were germinated in perlite sand; Ten days after germination (Seed were treated as germinated when the radical protruded from the envelopes), the young seedlings were transferred to pots containing peat moss soil. 60 days later, complete leaves were collected from each taxon, all the leaves were collected from the fifth nodes.

Stereo-microscope and light microscope were used for morphological measurement of the leaves.

\subsection{Statistical Analysis}

The extracted leaf characters were coded as 1 to 0 codes and used for numerical analysis; forty eight characters were recorded for each taxon. Phenogram illustrating the relationship between the studied taxa were constructed using the NTsys2.1 [11].

\section{Results and Discussion}

Considerable variation of leaf characters were observed among studied taxa as shown in Figures 1-3; for example, leaf consisted of 2 leaflets or 4 - 8 leaflets with their shape varying from elliptic, lanceolate, oblong, obovate to ovate. Leaflet apex was acute, acuminate, obtuse or truncate and the base was cuneate or obtuse. Leaf surface was hairy to glabrous. Stipules shape varied from sagittate to hastate with acute to forked base. Observed variations summarized in Table 1 and Table 2 enabled us to identify species.

Several natural systems had been constructed to divide the genus Vicia based on morphological characters such as stems, flowers, and fruits [12]-[17]. In addition to species identification, this work leaf characters were used to help in overcoming the overlapping among these systems.

In the natural system of [18], $V$. sativa subsp. nigra was treated as $V$. angustifolia subsp. pusilla; on the other side, [12] treated it as a subspecies of $V$. sativa; this suspicion may be dangerous as $V$. angustifolia is an important forage plant, belonging to the first group of fodder vetches [13], while $V$. sativa ssp. nigra is possibly contains gluco-alkaloids and neurotoxic cyanoamino acids which have toxic effect [19]. The phenogram in Figure 4 show that $V$. sativa subsp. nigra is more closely related to $V$. sativa $(0.2-0.5 \mathrm{~mm}$, acute, multicellular trichomes 
Table 1. Leaf characters of studied species.

\begin{tabular}{|c|c|c|c|c|c|c|c|c|c|c|c|c|c|}
\hline \multirow[b]{2}{*}{ Species } & \multirow{2}{*}{$\begin{array}{c}\text { Petiole } \\
\text { length } \\
(\mathrm{cm})\end{array}$} & \multicolumn{6}{|c|}{ Leaflets } & \multicolumn{6}{|c|}{ Trichomes } \\
\hline & & $\mathrm{N}$ & $\begin{array}{l}\text { Length } \\
(\mathrm{cm})\end{array}$ & $\begin{array}{l}\text { Width } \\
(\mathrm{mm})\end{array}$ & Shape & Apex & Base & Surface & Shape & Type & $\begin{array}{c}\text { Length } \\
(\mathrm{mm})\end{array}$ & $\begin{array}{c}\text { Distance } \\
(\mathrm{mm})\end{array}$ & Base \\
\hline V. amoena & $0.5-0.8$ & 2 & $1.9-2.2$ & $4-5$ & Lanceolate & Acute & Obtuse & Glabrous & - & - & - & - & - \\
\hline$V$. angustifolia & $0.8-1.1$ & 4 & $0.8-1.1$ & $2-3$ & Oblong & Acuminate & Obtuse & Hairy & Linear & Unicellular & $1-2$ & $0.1-0.3$ & Nonglandular \\
\hline$V$. bungei & $0.5-0.8$ & 2 & $0.9-1.2$ & $7-9$ & Obovate & Obtuse & Cuneate & Glabrous & - & - & - & - & - \\
\hline$V$. costata & $0.7-1.2$ & 2 & $0.7-0.9$ & $2-3$ & Oblong & Acuminate & Obtuse & Glabrous & - & - & - & - & - \\
\hline V. hirsuta & $0.5-0.7$ & 4 & $0.7-0.9$ & $2-3$ & Oblong & Truncate & Cuneate & Glabrous & - & - & - & - & - \\
\hline$V$. japonica & $0.3-0.5$ & 4 & $0.8-1$ & $3-4$ & Oblong & Obtuse & Cuneate & Glabrous & - & - & - & - & - \\
\hline $\begin{array}{c}\text { V. sativa } \\
\text { subsp. nigra }\end{array}$ & $0.7-1$ & 2 & $1.5-1.7$ & $3-4$ & Lanceolate & Acuminate & Obtuse & Hairy & Acute & Multicellular & $0.2-0.4$ & $0.1-0.5$ & Glandular \\
\hline $\begin{array}{c}\text { V. sativa } \\
\text { subsp. sativa }\end{array}$ & $0.8-1.2$ & 2 & $1.2-1.4$ & $4-5$ & Ovate & Acute & Obtuse & Hairy & Acute & Multicellular & $0.2-0.5$ & $0.2-0.5$ & Glandular \\
\hline V. tenuifolia & $0.7-1$ & 2 & $1.3-1.5$ & $4-5$ & Ovate & Acute & Cuneate & Hairy & Acute & Unicellular & $1-2$ & $0.6-0.8$ & Nonglandular \\
\hline$V$. tetrasperma & $0.7-1$ & 2 & $0.7-0.9$ & $2-3$ & Elliptic & Acute & Cuneate & Glabrous & - & - & - & - & - \\
\hline $\begin{array}{l}V . \text { villosa } \\
\text { subsp. } \\
\text { dasycarpa }\end{array}$ & $0.5-0.8$ & $\begin{array}{c}4- \\
8\end{array}$ & $0.8-1.1$ & $2-3$ & Oblong & Acuminate & Cuneate & Hairy & Linear & Unicellular & $1-2$ & $\begin{array}{l}\text { More } \\
\text { than } 2\end{array}$ & Nonglandular \\
\hline $\begin{array}{l}V \text {. villosa } \\
\text { subsp. varia }\end{array}$ & $0.3-0.4$ & 6 & $0.9-1.1$ & $2-3$ & Lanceolate & Acuminate & Cuneate & hairy & Acute & Unicellular & $1-2$ & $0.8-1.3$ & Nonglandular \\
\hline
\end{tabular}

Table 2. Stipules structure of studied species.

\begin{tabular}{|c|c|c|c|c|c|c|c|c|c|c|}
\hline Species & Shape & Base & $\begin{array}{c}\text { Length } \\
(\mathrm{mm})\end{array}$ & $\begin{array}{l}\text { Width } \\
(\mathrm{mm})\end{array}$ & $\begin{array}{l}\text { Blade } \\
\text { length } \\
(\mathrm{mm})\end{array}$ & $\begin{array}{l}\text { Base } \\
\text { length } \\
(\mathrm{mm})\end{array}$ & Surface & $\begin{array}{l}\text { Hair } \\
\text { length } \\
(\mathrm{mm})\end{array}$ & $\begin{array}{c}\text { Distance } \\
\text { between } \\
\text { trichomes } \\
(\mathrm{mm})\end{array}$ & $\begin{array}{l}\text { No. of } \\
\text { trichomes in } \\
\quad(1 \mathrm{~mm})\end{array}$ \\
\hline V.amoena & Sagittate & Acute & $1-1.2$ & $0.2-0.3$ & $0.5-0.6$ & $0.5-0.6$ & Smooth & - & - & - \\
\hline$V$. angustifolia & Sagittate & Acute & $1.5-1.7$ & $0.4-0.5$ & $0.8-1$ & $0.7-0.8$ & Hairy & $0.16-0.4$ & $0.08-0.1$ & $12-16$ \\
\hline V. bungei & Hastate & Acute & $2.5-2.7$ & $1.5-1.8$ & $0.3-0.4$ & $2.2-2.4$ & Smooth & - & - & - \\
\hline$V$. costata & Sagittate & Acute & $0.6-0.8$ & $0.2-0.3$ & $0.4-0.5$ & $0.2-0.3$ & Smooth & - & - & - \\
\hline$V$. hirsuta & Sagittate & Forked & $1.6-2$ & $0.4-0.5$ & $0.8-1$ & $0.8-1$ & Smooth & - & - & - \\
\hline$V$. japonica & Sagittate & Acute & $1.8-2$ & $0.4-0.5$ & $1-1.2$ & $0.8-0.9$ & Smooth & - & - & - \\
\hline V. sativa subsp. nigra & Sagittate & Acute & $2.1-2.4$ & $0.2-0.3$ & $1.3-1.4$ & $0.8-1$ & Hairy & $0.08-0.16$ & $0.008-0.16$ & $5-7$ \\
\hline V. sativa subsp. sativa & Sagittate & Forked & $3.5-3.8$ & $0.4-0.5$ & $2.3-2.5$ & $1.2-1.4$ & Hairy & $0.16-0.28$ & $0.12-0.36$ & $7-9$ \\
\hline$V$. tenuifolia & Sagittate & Acute & $1.5-1.8$ & $0.2-0.3$ & $1.2-1.4$ & $0.3-0.4$ & Smooth & - & - & - \\
\hline V. tetrasperma & Hastate & Acute & $1-1.2$ & $0.2-0$ & $0.8-1$ & $0.2-0.3$ & Smooth & - & - & - \\
\hline V. villosa subsp. dasycarpa & Hastate & Acute & $2-2.2$ & $0.4-0.5$ & $1.7-1.9$ & $0.3-0.4$ & Smooth & - & - & - \\
\hline$V$. villosa subsp. varia & Sagittate & Acute & $1.3-1.5$ & $0.4-0.5$ & $1-1.1$ & $0.3-0.4$ & Hairy & $0.16-0.2$ & $0.1-1$ & $3-4$ \\
\hline
\end{tabular}

with glandular base) and not to $V$. angustifolia (1 - $2 \mathrm{~mm}$, linear, unicellular trichomes with non-glandular base) supporting the classification of [12].

An artificial key to Vicia species was constructed as follow: 


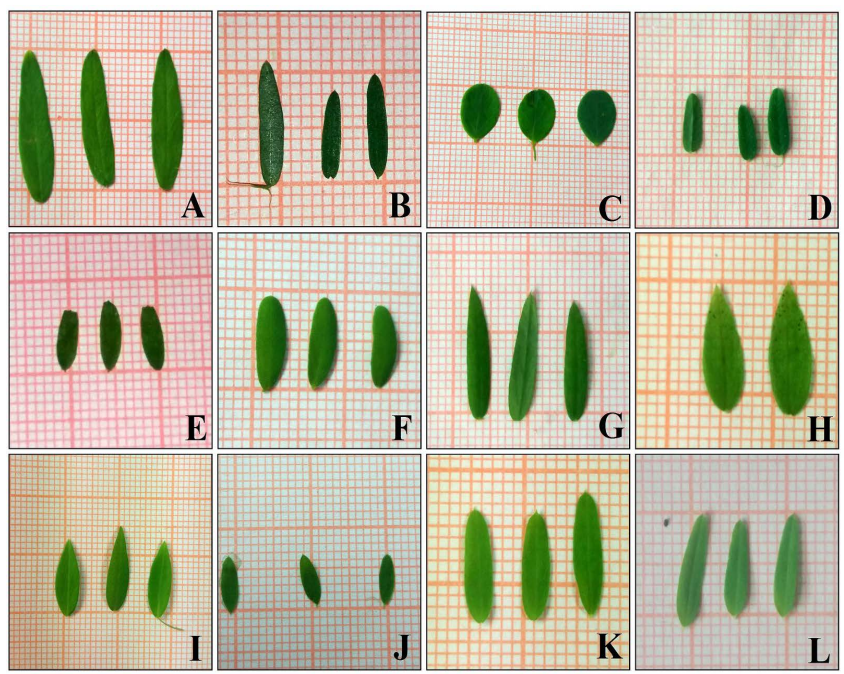

Figure 1. Leaflets structure in studied Vicia species. (A) V. amoena; (B) V. angustifolia; (C) V. bungei; (D) V. costata; (E) V. hirsuta; (F) V. japonica; (G) V. sativa subsp. Nigra; (H) V. sativa subsp. Sativa; (I) V. tenuifolia; (J) V. tetrasperma; (K) V. villosa subsp. dasycarpa; (L) V. villosa subsp. varia.
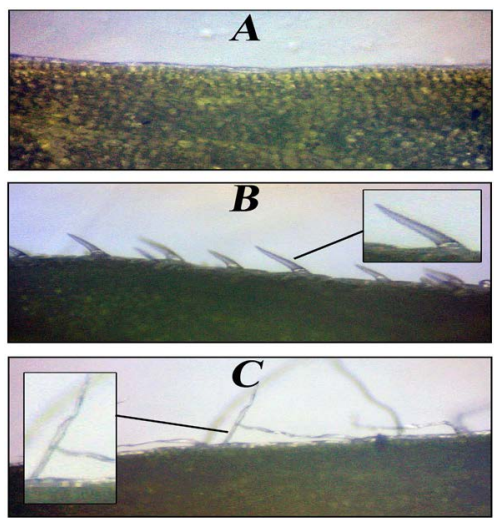

Figure 2. Blade surface in studied Vicia species. (A) Smooth surface; (B) Glandular trichomes; (C) Non-glandular trichomes.

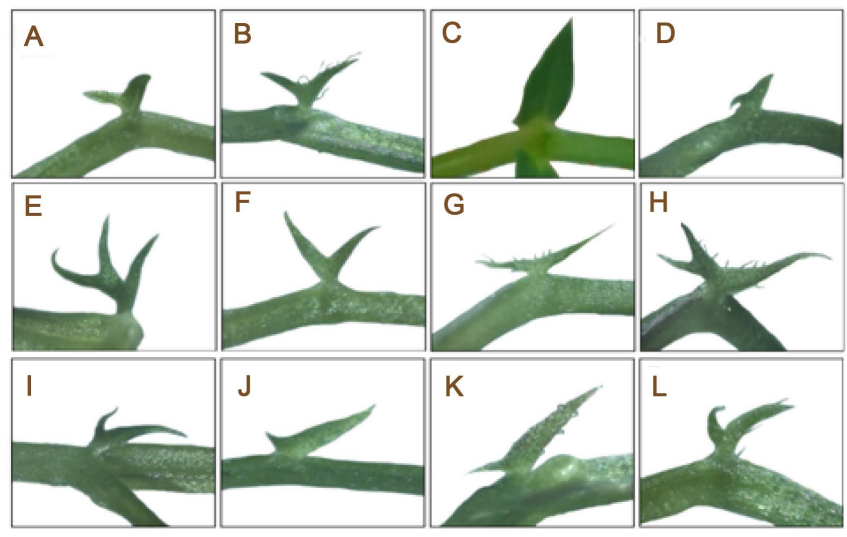

Figure 3. Stipules structure in studied Vicia species. (A) V. amoena; (B) V. angustifolia; (C) V. bungei; (D) V. costata; (E) V. hirsuta; (F) V. japonica; (G) V. sativa subsp. nigra; (H) V. sativa subsp. sativa; (I) V. tenuifolia; (J) V. tetrasperma; (K) V. villosa subsp. dasycarpa; (L) V. villosa subsp. varia. 


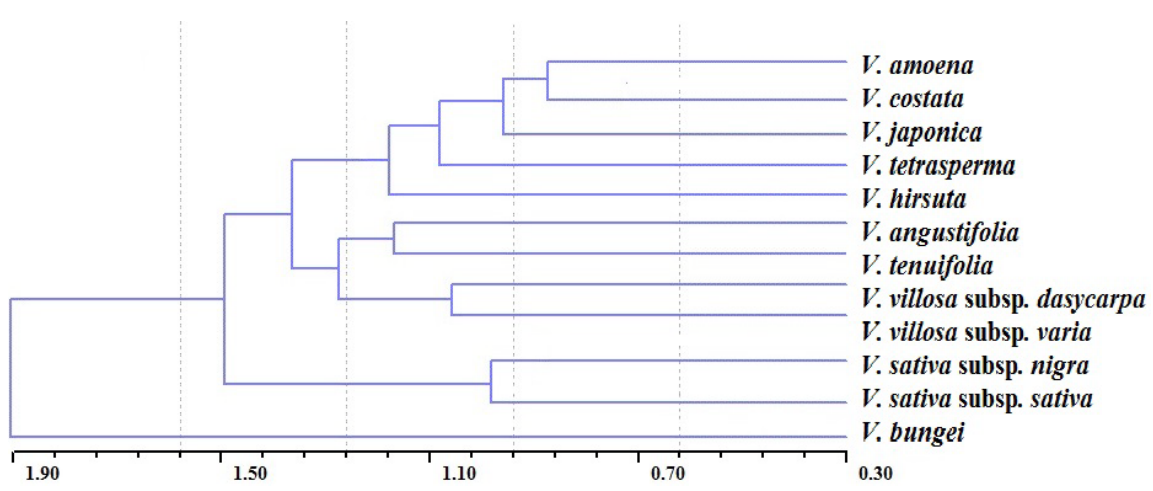

Figure 4. Phenogram illustrating the relationships between the studied Vicia species on the bases of the micro morphological characters of the leaf, the total number of the recorded characters is (48) in each taxon.

1a. Leaflets obovate,

1b. Leaflets elliptic

2a. Blade with multicellular trichomes

2b. Blade smooth or with unicellular trichomes

3a. Leaflets ovate. Stipules base forked

3b. Leaflets lanceolate. Stipules base acute

4a. Leaflets blade hairy

4b. Leaflets blade smooth

5a. Leaflets oblong. Blade surface with linear trichomes
V. bungei

V. sativa subsp. sativa

V. sativa subsp. nigra

5b. Leaflets lanceolate or ovate. Blade surface with acute trichomes (7)

6a. Blade with 0.1 to $0.5 \mathrm{~mm}$ distances between trichomes. Stipules with hairy surface

V. angustifolia

6b. Blade with more than $2 \mathrm{~mm}$ distances between trichomes. Stipules with smooth surface

7a. Leaf with 2 leaflets

$V$. villosa subsp. dasycarpa

7b. Leaf with 4-8 leaflets

$V$. tenuifolia

8a. Stipules with forked base

V. villosa subsp. varia

$\mathbf{8 b}$. Stipules with acute base

V. hirsuta

9a. Leaflets elliptic. Stipules hastate

(9)

9b. Leaflets lanceolate or oblong. Stipules sagittate

V. tetrasperma

10a. Leaflets with obtuse apex and cuneate base

10b. Leaflets with acute or acuminate apex and obtuse base

11a. Leaflets oblong

V. costata

11b. Leaflets lanceolate

V. amoena

In conclusion, our results show that leaf morphological characters are variable and helpful in distinguishing various species and could be used to construct an artificial key to identify Vicia species.

\section{Acknowledgements}

This study was supported by the National Natural Science foundation of China (Grant No. 31370007). 


\section{References}

[1] Ogundipe, O. and Kadiri, A. (2012) Comparative Foliar Epidermal Morphology of the West African Species of Amaranthaceae Juss. Feddes Repertorium, 123, 97-116. https://doi.org/10.1002/fedr.201100003

[2] Fatihah, H.N.N., Nashriyah, M., Zaimah, A.R.N., Khairil, M. and Ali, A.M. (2014) Leaf Morphology and Anatomy of 7 Varieties of Ficus deltoidea (moraceae). Turkish Journal of Botany, 38, 677-685. https://doi.org/10.3906/bot-1301-7

[3] Trujillo-Moya, C., Peiro, R. and Gisbert, C. (2014) Leaf Morphology and Shoot Regeneration of in Vitro Cultured Explants from Species of the Solanum peruvianum sl Complex. Turkish Journal of Botany, 38, 465-476. https://doi.org/10.3906/bot-1305-16

[4] Kadiri, A.B. and Olowokudejo, J.D. (2008) Comparative Foliar Epidermal Morphology of the West African Species of the Genus Afzelia smith (leguminosae: Caesalpinioideae) [estudio comparativo de la epidermis de la hoja de species del genero Afzelia smith (leguminosae: Caesalpinioideae) de africa occidental]. Gayana Botanica, 65, 84 .

[5] Ogundipe, O., Kadiri, A. and Adekanmbi, O. (2009) Foliar Epidermal Morphology of Some Nigerian Species of Senna (Caesalpiniaceae). Indian Journal of Science and Technology, 2, 5-9.

[6] Mirzaei, L., Assadi, M., Nejadsatari, T. and Mehregan, I. (2015) Comparative Seed and Leaf Micromorphology of Colutea Species (fabaceae) from Iran. Environ Exp Biol, 13, 183-187.

[7] Albert, S. and Sharma, B. (2013) Comparative Foliar Micromorphological Studies of Some Bauhinia (Leguminosae) Species. Turkish Journal of Botany, 37, 276-281.

[8] Grohar, M., Rosenfeldt, S. and Morales, M. (2016) Leaflet Trichome Micromorphology in the Dolentes-Brevipedes Taxonomic Complex (Mimosa 1., Mimosoideae). Turkish Journal of Botany, 40, 45-58. https://doi.org/10.3906/bot-1412-40

[9] Bisby, F., Zarrucchi, J., Schrire, B., Roskov, Y. and White, R. (1999) Ildis World Database of Legumes.

[10] Hanelt, P. and Mettin, D. (1989) Biosystematics of the Genus Vicia L. (Leguminosae). Annual Review of Ecology and Systematics, 199-223. https://doi.org/10.1146/annurev.es.20.110189.001215

[11] Rohlf, F. (2000) Ntsys-pc: Numerical Taxonomy (Vitis vinifera L.) Varieties Using Morphological Data and Multivariate Analysis System. Exeter Software, and Aflp Markers. Elect J Biotechnol, 6, 37-45.

[12] Gunn, C.R. (1979) Genus Vicia, with Notes about Tribe Vicieae (Fabaceae) in Mexico and Central America. 1601, US Dept. of Agriculture, Science and Education Administration.

[13] Komarov, V.L. (1972) Flora of the USSR. Vol. XIII. Leguminosae: Oxytropis, Hedysarum. Israel Program for Scientific Translations, Jerusalem.

[14] Davis, P. (1970) Flora of Turkey. University Press, Edinburg, Vol. 3, 274-366.

[15] Kupicha, F. (1976) The Infrageneric Structure of Vicia. Notes R Bot Gard Edinb, 34, 287-326.

[16] Cui, H.B. (1998) Floras of China. Science Press, Beijing, Vol. 42, 232.

[17] Leht, M. (2005) Cladistic and Phenetic Analyses of Relationships in Vicia Subgenus Cracca (Fabaceae) Based on Morphological Data. Taxon, 54, 1023-1032. https://doi.org/10.2307/25065486

[18] Boissier, E. (1872) Flora orientalis. Genevae \& Basileae, 2, 574-582.

[19] Everist, S.L. (1974) Poisonous Plants of Australia. Angus \& Robert Son, Sydney. 
Submit or recommend next manuscript to SCIRP and we will provide best service for you:

Accepting pre-submission inquiries through Email, Facebook, LinkedIn, Twitter, etc. A wide selection of journals (inclusive of 9 subjects, more than 200 journals)

Providing 24-hour high-quality service

User-friendly online submission system

Fair and swift peer-review system

Efficient typesetting and proofreading procedure

Display of the result of downloads and visits, as well as the number of cited articles Maximum dissemination of your research work

Submit your manuscript at: http://papersubmission.scirp.org/

Or contact jbm@scirp.org 